Federal Reserve Bank of Dallas

Globalization and Monetary Policy Institute

Working Paper No. 232

http://www.dallasfed.org/assets/documents/institute/wpapers/2015/0232.pdf

\title{
Global Financial Market Impact of the Announcement of the ECB's Extended Asset Purchase Programme*
}

\author{
Georgios Georgiadis \\ European Central Bank \\ Johannes Gräb \\ European Central Bank
}

March 2015

\begin{abstract}
We estimate the impact of the ECB's announcement of the extended asset purchase programme (EAPP) on 22 January 2015 on global equity prices, bond yields and the euro exchange rate. We find that the EAPP announcement benefited global financial markets by boosting equity prices in the euro area and the rest of the world. At the same time, the EAPP announcement caused a depreciation of the euro vis-à-vis advanced and emerging market economy currencies. Comparing the EAPP to previous ECB announcements of unconventional monetary policies, the main channel of transmission of the EAPP announcement to global financial markets was through signalling-the ECB convincingly conveying to market participants that its future monetary policy stance will remain accommodative - rather than through improving confidence (as was the case for the OMT) or through portfolio re-balancing (as for the SMP). Similarly, in contrast to the OMT and the SMP announcements the signaling channel also played a major role for the domestic financial market impact of the EAPP. Cross-country heterogeneities in the global financial market spillovers from the EAPP announcement were linked to differences in economies' financial openness, exchange rate regime, trade and financial integration with the euro area and their attractiveness for carry trades.
\end{abstract}

JEL codes: E52, E58, G15

\footnotetext{
* Georgios Georgiadis, European Central Bank, 60311 Frankfurt am Main, Germany. 49-69-1344-5851. georgios.georgiadis@ecb.int Johannes Gräb, European Central Bank, 60311 Frankfurt am Main, Germany. 49-69-1344-5120. johannes.graeb@ecb.int. We would like to thank Thomas Kostka, Arnaud Mehl, Sandra Rhouma and Livio Stracca. The views in this paper are those of the authors and do not necessarily reflect the views of the European Central Bank, the Federal Reserve Bank of Dallas or the Federal Reserve System.
} 


\section{Introduction}

Against the background of falling inflation across the euro area, on 22 January 2015 the ECB announced an extended asset purchase programme (EAPP) under which it would engage in monthly purchases of sovereign bonds of 60 billion euro at least until September 2016. Knowledge about the impact of this policy measure on domestic and foreign financial markets is crucial for the calibration of future policy both in the euro area and abroad, given the strong integration of the global economy. In particular, in the euro area the perceived trade-off between the expansionary effects of the EAPP and possible financial stability risks will determine whether such an unconventional monetary policy measure will be an option in the future. In emerging market economies, policymakers need to be aware of possible capital flows to their financial markets which might fuel asset price bubbles and exchange rate over-valuations.

Unconventional monetary policy measures are typically discussed and partly anticipated by financial markets well before they are actually implemented. This renders it difficult to identify the overall effect of announcements of unconventional monetary policy measures using event-study frameworks. Indeed, the EAPP was partly anticipated by markets before its announcement due to information spread gradually in the weeks prior to the ECB's Governing Council meeting of 22 January 2015. As a result, the impact of the announcement on 22 January 2015 presumably only reflects a fraction of the overall global financial market effect of all EAPP-related news. ${ }^{1}$ For this reason, in this paper rather than estimating the total effect we confine ourselves to studying the effect of the announcement of the EAPP on 22 January 2015. Specifically, our goal is (i) to assess the patterns of global financial market responses to the EAPP announcement on 22 January 2015 across asset classes and regions; (ii) to compare the effects of the EAPP announcement on 22 January 2015 with those of other major ECB announcements of unconventional policy measures; (iii) to assess the relative importance of the transmission channels; and finally (iv) to explain the cross-country heterogeneity in the impact of the

\footnotetext{
${ }^{1}$ Of course, one could argue that focusing on the effects of the EAPP announcement of 22 January 2015 represents a lower bound estimate of the total effects.
} 
EAPP announcement on 22 January 2015. In order to do so, we do require some surprise component in the EAPP announcement on 22 January 2015: While market expectations concerning the total volume of purchases amounted to 500-700 billion euros according to Reuters polls, the ECB announced that the EAPP would involve purchases of more than 1 trillion euros; moreover, markets were surprised by the open-ended character of the purchase programme, which is intended to be carried out until at least September 2016 and in any case until the Governing Council sees a sustained adjustment in the path of inflation that is consistent with its aim of achieving inflation rates below but close to $2 \%$ over the medium term.

Our paper is related to the literature on the global financial market effects of unconventional monetary policy measures. This literature has mostly resorted to event studies in order to gauge the responses of global financial markets to announcements of unconventional measures in the US. The findings in this literature generally suggest that US unconventional monetary policies had large asset price and capital flow spillovers (Neely, 2010; Fratzscher et al., 2013; Moore et al., 2013; Rogers et al., 2014). Bowman et al. (2014) employ VAR models and identification through heteroskedasticity and find that unconventional monetary policies in the US had a large impact on emerging market economies with substantive cross-country heterogeneity. And Bauer and Neely (2014) study the international transmission channels of US unconventional measures based on dynamic term structure models, finding that there were some differences in the relative importance of the signalling and portfolio re-balancing channels across major advanced economies. ${ }^{2}$

In contrast to the US case, only few studies have investigated the global effects of previous ECB unconventional monetary policy measures, i.e. the Securities Markets Programme (SMP) and the Outright Monetary Transactions (OMT). In particular, Fratzscher et al. (2014) consider the global asset price reactions to these ECB unconventional monetary policies, finding that they boosted global equity markets, lowered credit risk among G20 banks and sovereigns, but that they did not lead to international portfolio re-balancing

\footnotetext{
${ }^{2}$ Ahmed and Zlate (2014) find that while capital flows to emerging market economies did not systematically increase in response to US unconventional monetary policies their composition shifted towards more volatile portfolio flows.
} 
across regions and asset classes. Comparing the impact of unconventional monetary policy measures in the US, the UK, Japan and the euro area, Rogers et al. (2014) find that ECB unconventional measures had much smaller-if any-global spillovers than those in the $\mathrm{US}^{3}$

Our contribution to this literature is fourfold. First, we study patterns of global financial markets responses to the ECB's most recent announcement of an unconventional monetary policy measure, the EAPP, across asset classes and regions. Second, we test explicitly for the empirical relevance of the signalling, portfolio re-balancing and confidence channel in the transmission of the EAPP announcement to global financial markets; moreover, we compare the transmission of the EAPP announcement to global financial markets to those of previous ECB unconventional monetary policy measures, i.e. the OMT and the SMP. Third, we analyse the cross-country heterogeneity in the impact of the EAPP announcement building on a gravity-type foundation of asset price movements. Finally, we carefully consider price fixing times for global asset prices such that the likelihood that our estimates for the effects on global financial markets are driven by non-EAPP related events is minimised.

We find that the ECB's EAPP announcement on 22 January 2015 caused a broad-based depreciation of the euro and a boost in euro area as well as global equity prices, while the impact on bond prices was muted. Across regions, both equity markets and exchange rates reacted slightly stronger in emerging market economies compared to advanced economies. Looking at transmission channels, global equities benefited from positive confidence effects, while euro area equities gained through signalling, confidence and portfolio rebalancing channels. The ECB's signalling that its future monetary policy stance will remain accommodative was the major driver for the depreciation of the euro. Compared to previous major ECB announcements of unconventional monetary policy measures we find that only the EAPP announcement on 22 January 2015 had an immediate impact

\footnotetext{
${ }^{3}$ Fic (2013) constructs an index of global quantitative easing which summarises the unconventional monetary policy measures taken in the US, the UK, the euro area and Japan, finding that the latter appreciated developing economies' exchange rates and lowered their long-term yields. Kawai (2015) considers the impact of unconventional monetary policy in Japan on emerging Asia finding that its impact has been positive.
} 
on the euro exchange rate. Euro area equities benefited only from the EAPP and the OMT announcements; confidence effects were more important with the OMT and portfolio re-balancing and signalling channel with the EAPP announcement. While global equity prices responded to announcements of all major ECB unconventional monetary policy measures, confidence effects were dominant for the EAPP and the OMT while portfolio re-balancing was the major driver for the SMP announcement. Finally, we find that cross-country heterogeneities in the global financial market spillovers from the EAPP announcement on 22 January 2015 were linked to differences in economies' financial openness, exchange rate regime, trade and financial integration with the euro area and their attractiveness for carry trades.

The rest of the paper is organised as follows. Section 2 lays out our empirical framework and describes our data. Our results are presented in Section 3. Finally, Section 4 concludes.

\section{Econometric Model}

In order to estimate the impact of the EAPP announcement on 22 January 2015 on global financial markets we consider a standard event-study framework that allows us to control for non-EAPP related market news (see, for example, Fratzscher et al., 2014; Rogers et al., 2014). Specifically, we consider the regression

$$
\begin{aligned}
y_{i, t}^{(j)}=\alpha_{i}+\beta_{1} E A P P_{E A, t}+\beta_{2} \operatorname{Surpr}_{i, t}+\beta_{3} \operatorname{Surpr}_{E A, t}+ & \beta_{4} \operatorname{Surpr}_{U S, t}+\epsilon_{i, t}, \\
j & \in\{F X, \text { Equities, Bonds }\}
\end{aligned}
$$

where the dependent variable $y_{i, t}$ is either (i) the percentage change in the euro bilateral exchange rate vis-à-vis country $i$ 's currency, (ii) the change in country $i$ 's ten-year government bond yield (in percentage points), or (iii) the return on country $i$ 's major stock market index. The explanatory variable of interest is the dummy variable $E A P P_{E A, t}$ which equals unity on 22 January 2015, and the control variables include contemporane- 
ous surprises in macroeconomic data releases in the euro area, the US and country $i .^{4}$ The estimation sample is daily, spans the time period from 1 January 2007 to 31 January 2015 and the euro area's 39 major trading partners. ${ }^{5}$

The ECB announced the EAPP in a press conference on 22 January at 2.30pm Frankfurt time (1.30pm London time, 10.30pm Tokyo time, 8.30am New York time). In order to identify the impact of the EAPP announcement in daily data, we need to consider fixing times for equity prices, bond yields and exchange rates after the EAPP announcement at $2.30 \mathrm{pm}$ Frankfurt time. At the same time, we want to choose fixing times that are as close to each other as possible across jurisdictions in order to preclude that differences in our estimates of the financial market responses are due to differences in the time elapsed after the EAPP announcement. As a result, for exchange rates we consider New York fixings as they are traded 24 hours around the clock. In contrast, for most economies' bonds and equities we consider local closing time fixings as these assets are not traded around the clock. For Asian equity prices we consider opening time fixings in $t+1$ as local markets are already closed when announcements in the euro area occur. Finally, for Asian bond yields we resort to closing time fixings in $t+1$ as Bloomberg does not report opening time fixings. ${ }^{6}$

\section{Results}

\subsection{Exchange rate effects and global financial market impact}

Table 2 reports our findings for major advanced economies and country groups. ${ }^{7}$ In particular, our results suggest that the EAPP announcement caused a broad-based depreciation

\footnotetext{
${ }^{4}$ More specifically, we consider the Citigroup Economic Surprise Indices which are calculated as the normalised deviation of the actual data release from the market consensus prior to the release. For countries for which Surprise Indices are not provided we use the respective regional indices.

${ }^{5}$ See Table 1 for details.

${ }^{6} \mathrm{We}$ consider closing prices in $t+1$ for all bonds and opening prices in $t+1$ for all equity indices in robustness checks in Section 3.4.

${ }^{7}$ In order to aggregate results to the country-group level we use euro area trade weights in case of the euro exchange rate and GDP weights in case of bond and equity returns.
} 
of the euro vis-à-vis its major trading partners. ${ }^{8}$ The depreciation of the euro was less pronounced against advanced economies $(-1.4 \%)$ than against emerging market economies $(-2.4 \%)$. However, this finding masks substantial heterogeneity in the exchange rate impact among advanced economies. In particular, the euro weakened markedly against the US dollar $(-2.1 \%)$ and the Japanese yen $(-1.7 \%)$, but less so against the currencies of its neighboring countries in the EU (-1\%) and of non-EU advanced economies $(-1 \%)$. In turn, among emerging market economies the depreciation of the euro was most pronounced against currencies in Central Europe, Middle-East and Africa (CEMEA) and Latin America (around -3\%), but less pronounced against Asian currencies (-2.1\%).

Equity prices increased across the globe in response to the EAPP announcement. Equity markets benefited somewhat more strongly in EMEs, in particular in Asia (+2.5\%) and CEMEA $(+1.9 \%)$. Stock markets also jumped markedly the euro area $(+1.7 \%)$ and the US $(+1.5 \%)$. In contrast to equities and the euro exchange rate, the immediate impact of the EAPP announcement on global bond yields was muted: Sovereign bond yields were stable across advanced and emerging market economies, with the exception of euro area, Japanese and Asian emerging markets economies where sovereign bond yields declined somewhat. ${ }^{9}$ The limited decline in global sovereign bond yields may be explained by the already very low yields, in particular in many advanced economies. The finding that lower sovereign yields in the euro area did not generally drag down yields in other advanced economies - including the US - is consistent with the results of existing studies on previous ECB announcements of conventional and unconventional monetary policy measures (see Ehrmann and Fratzscher, 2005; Fratzscher et al., 2014; Rogers et al., 2014).

\footnotetext{
${ }^{8}$ For the effects on the euro exchange rate we drop Bulgaria and Denmark from the sample as their currency is pegged to the euro.

${ }^{9}$ Notice that the difference in the results for bond yields between Asian economies and the rest of the world may be due to us using closing time fixings on the day following the EAPP announcement on 22 January 2015 in our baseline regression. Below we report robustness checks in which we consider closing prices for bonds for all countries.
} 


\subsection{Transmission channels}

In order to shed light on the transmission channels that underpinned the global financial market impact of the ECB's EAPP announcement on 22 January 2015, we empirically test for the signalling, portfolio re-balancing and confidence channel. These are the main transmission channels through which announcements of unconventional monetary policies can affect asset prices, both domestically and internationally. In order to test empirically for these channels, we modify Equation (1) to

$$
\begin{aligned}
y_{i, t}^{(j)}= & \alpha_{i}+\beta_{1} E A P P_{E A, t}+\beta_{2} \text { Surpr }_{i, t}+\beta_{3} \operatorname{Surpr}_{E A, t}+\beta_{4} \operatorname{Surpr}_{U S, t}+\epsilon_{i, t}, \\
& j \in\{V I X, \text { EAspread, Inflation expectations, Bond flows, Equity flows }\}
\end{aligned}
$$

In particular, in order to test for confidence effects, we consider two measures of investor confidence as alternative dependent variables in Equation (2). First, we consider the VIX as a measure for global investors' risk appetite. Second, we consider intra-euro area sovereign bond yield spreads as a proxy for euro area-specific risk aversion. ${ }^{10}$ We test for the signalling channel by examining the impact of the EAPP announcement on real interest rates. ${ }^{11}$ Finally, we follow Fratzscher et al. (2013) and consider high-frequency data on international portfolio flows to test for the portfolio re-balancing channel. ${ }^{12}$ The results for these additional dependent variables are reported in Table 3.

\subsubsection{Domestic financial market impact}

For the domestic financial market impact of the EAPP announcement on 22 January 2015, our results are consistent with (i) the boost in euro area equities having been driven by the signalling, confidence and portfolio re-balancing channel, and (ii) the fall in euro

\footnotetext{
${ }^{10}$ Intra-euro area bond yield spreads are calculated as the difference between the ten-year sovereign bond yields in Italy and Germany.

${ }^{11}$ Real interest rates are derived from nominal bond yields and inflation expectations. For inflation expectations we consider data on ten-year zero-coupon inflation-linked euro area government bonds.

${ }^{12} \mathrm{We}$ consider weekly debt and equity flows and therefore the cumulative flows up to one week after the announcement.
} 
area sovereign bond yields having occurred through the confidence channel. In particular, euro area equity valuations were supported by a decline in real interest rates that resulted from falling local bond yields and a rise in inflation expectations as a consequence of the ECB convincingly signalling that its future monetary policy stance would remainespecially relative to that in the US - accommodative (the signalling channel). Moreover, euro area equities benefited from investor re-balancing from non-euro area into euro area equities (the portfolio re-balancing channel). Finally, euro area equities also benefited from positive confidence effects reflected in a fall in the VIX in response to the EAPP announcement; this is also consistent with the fall in the intra-euro area bond yield spread. In contrast, the results do not provide evidence for portfolio re-balancing into euro area bonds, leaving confidence effects as the only explanation for the fall in their yields.

\subsubsection{Global financial market impact}

Concerning the global financial market spillovers from the EAPP announcement on 22 January 2015 the results are consistent with (i) the rise in non-euro area equity prices having been driven by positive confidence effects, and (ii) the depreciation of the euro exchange rate having occurred through the signalling channel and, to a lesser extent, the portfolio re-balancing channel. In particular, the results suggest that non-euro area equity returns benefited from an increase in investors' risk appetite as reflected in the fall in the VIX. This finding may partly reflect abating concerns of market participants over the long-run growth and inflation prospects of the euro area. In particular, positive confidence effects have more than offset the negative implications of the portfolio rebalancing out of foreign into euro area equity markets that has been observed after the announcement of 22 January. Moreover, the results suggest that the depreciation of the euro was driven by a fall in euro area real interest rates (the signalling channel), in particular in view of the expectation of monetary normalisation in the US. This suggests that the announcement reinforced the significant and increasing differences in the monetary policy cycles of the major advanced economies. Importantly, we find that only the signalling channel is consistent with the finding of depreciation pressures on the euro exchange rate: the 
confidence channel should, ceteris paribus, have supported the euro exchange rate, at least against the US dollar and the Japanese yen, the ultimates safe haven currencies. Similarly, portfolio re-balancing should also have prevented a stronger depreciation of the euro given the observed pattern of portfolio re-balancing into euro area equity markets. Finally, low bond inflows into the euro area relative to the US and advanced economies as a whole suggest some portfolio re-balancing into US relative to euro area bond markets.

\subsection{Comparison to previous ECB unconventional measures}

It is also insightful to contrast the effects and transmission channels of the EAPP announcement on 22 January 2015 to those of previous ECB announcements of unconventional monetary policy actions, namely the announcements of the SMP programme in 2010 and 2011 as well as the OMT in 2012. We obtain estimates for the impact of the OMT and SMP announcements on asset prices and for their transmission channels from regressions of Equation (1) replacing the EAPP dummy by an OMT or an SMP dummy. ${ }^{13}$ Results for the impact of these announcements on asset prices and transmission channels are reported in Tables 4 and 5 and plotted in Figure 1.

\subsubsection{Domestic and global impact}

Regarding the domestic effects the major difference across the ECB's announcements of unconventional monetary policy measures is that equity prices increased in response to the EAPP and the OMT but not after the SMP announcement, and that in contrast to the EAPP announcement on 22 January 2015 the OMT and the SMP announcements led to a marked decline in intra-euro area sovereign bond yield spreads. The upper panel of Figure 1 shows that in response to the OMT announcement euro area equities benefited strongly,

\footnotetext{
${ }^{13}$ The OMT dummy equals unity on 26 July 2012 ("Whatever it takes") and 6 September 2012 (Governing Council statement on OMT modalities). Likewise, the SMP dummy equals unity on 10 May 2010 (introduction of SMP) and 8 August 2011 (re-activation of SMP). The results for the financial market impact of the OMT and SMP announcements are similar to those reported in Fratzscher et al. (2014) and Rogers et al. (2014).
} 
even more than after the EAPP announcement; in contrast, euro area equities did not respond to the SMP announcement. Euro area sovereign bond yields fell in response to the EAPP but increased after the OMT announcement, albeit the magnitudes were minuscule. ${ }^{14}$

The major difference in the global spillovers across the ECB's announcements of unconventional monetary policy measures is the marked depreciation of the euro in response to the EAPP announcement. Specifically, while the euro depreciated broadly after the EAPP announcement, the immediate response to the OMT and the SMP announcements was rather limited. ${ }^{15}$ Moreover, the magnitude of spillovers to equity prices was largely similar across the EAPP, the OMT and the SMP announcements. Similarly to the EAPP announcement, the responses of global bond yields to the OMT and SMP announcements were rather muted.

\subsubsection{Differences in transmission channels}

The lower panel of Figure 1 shows that concerning the domestic effects of the ECB's announcements euro area equity prices were boosted through the signalling, confidence and portfolio re-balancing channel in case of the EAPP announcement, while they benefited mainly through the confidence channel in case of the OMT announcement. In particular, real interest rates remained broadly unchanged in response to the OMT announcement as sovereign bond yields increased in tandem with inflation expectations (see Table 5); and equity flows to the euro area did not increase in response to the OMT announcement. However, the OMT announcement markedly reduced both global and euro area-specific risk aversion leading to positive confidence effects.

The lower panel of Figure 1 suggests that the three ECB announcements of unconventional

\footnotetext{
${ }^{14}$ Obviously, in contrast to the EAPP announcement sovereign bond yields in stressed euro area countries declined sharply in response to the OMT and SMP announcements (see Table 5).

${ }^{15}$ While the immediate response of the euro exchange rate to the OMT announcement was muted, considerable evidence suggests that the gradual return of investors confidence caused by the OMT was among the main drivers of the broad-based and sustained appreciation of the euro in the second half of 2012 .
} 
monetary policy action also impacted global financial markets through different channels. In particular, the transmission of the EAPP and the OMT announcements to non-euro area equities were all driven by confidence effects: the VIX fell and the relative magnitudes of the fall across the EAPP and the OMT announcements is consistent with the relative increase in equity prices. In contrast, the decline in equity prices in response to the SMP announcement is consistent with portfolio re-balancing: advanced and emerging market economies experienced equity outflows.

\subsection{Robustness checks}

We explore the sensitivity of our results to (i) using different price fixing times, and (ii) considering a wider set of EAPP announcements. Specifically, we change the price fixing time of the bilateral euro exchange rate from New York fixing time to London fixing time. Moreover, for equity indices we consider opening prices on the day following the ECB's EAPP announcement for all countries rather than only for Asian economies, while we consider closing prices in $t+1$ for all bond yields. In order to expand the set of EAPPrelated announcements, we additionally consider the ECB Governing Council meeting of 4 September 2014, when the ECB announced it would launch an asset purchase programme (APP) which involved asset-backed securities and covered bonds and which was extended on 22 January 2015 to include sovereign bond purchases (the EAPP). ${ }^{16}$

The outcomes of these robustness checks are reported in Table 6. The results are very similar to those from our baseline when changing the price fixing times for exchange rates and equities. For sovereign bond yields, the analysis suggests that yields in advanced economies dropped significantly on the day following the ECB's EAPP announcement, while they had remained broadly unchanged on the day of the announcement. This may reflect gradual portfolio re-balancing of large international investors such as government pension funds. This would be in line with the finding of a portfolio re-balancing into US bond markets in our baseline results above.

\footnotetext{
${ }^{16}$ Specifically, for theses regressions the dummy $E A P P_{E A, t}$ equals unity both on 4 September 2014 and 22 January 2015.
} 
Finally, our results are qualitatively similar to the baseline when we add 4 September 2014 as an additional EAPP-related announcement. Quantitatively, the financial market impact appears to be weaker, which may reflect the much smaller scope of the APP relative to the EAPP regarding the total volume of purchases.

\subsection{Cross-country heterogeneities in the impact of the EAPP announcement}

The global financial market impact of the ECB's EAPP announcement on 22 January 2015 differed across economies, even within the country groups we have considered so far. In order to shed light on why asset prices in some economies responded more strongly to the EAPP announcement we build on a gravity-type framework of movements in asset prices (see Martin and Rey, 2004; Portes and Rey, 2005)

$$
\begin{aligned}
& \widehat{\beta}_{1 i}^{(j)}=\alpha+\delta_{1} \text { Dist }_{i}+\delta_{2} l G D P_{i}+\delta_{3} G F A L 2 G D P_{i}+\delta_{4} \text { Trade } E_{i} \\
& +\delta_{5} \text { FinIntE } A_{i}+\delta_{6} i D i f f_{i}+u_{i}, \quad j \in\{F X, \text { Equities, Bonds }\},
\end{aligned}
$$

where the estimates $\widehat{\beta}_{i 1}^{(j)}$ are obtained from country-specific versions of the regressions in Equation (1). Specifically, the explanatory variables include standard gravity-type variables (geographic distance to the euro area and country size, Dist $t_{i}$ and $l G D P_{i}$ ), variables reflecting financial openness and integration (the gross foreign asset and liability position relative to GDP, GFAL2GDP $P_{i}$ ), measures of the strength of an economy's bilateral integration with the euro area (the shares of an economy's total trade and financial integration that is accounted for by the euro area, TradeE $A_{i}$ and FinIntE $A_{i}$ ), and a measure of the attractiveness of economy $i$ for carry trades (the interest rate differential, $i D i f f_{i}$ ); for the case of the asset price change under consideration being the exchange rate we also enter the exchange rate regime as explanatory variable.

The results for the regressions in Equation (3) are reported in Table 7. Specifically, exchange rates, equity prices and bond yields responded more strongly to the ECB's EAPP 
announcement on 22 January 2015 in economies which are more financially integrated with the rest of the world overall. Moreover, currencies under a more flexible exchange rate regime displayed a stronger depreciation. Equity prices responded more and exchange rates less strongly to the EAPP announcement in economies with stronger trade and financial integration with the euro area, which is consistent with their closer business cycle correlation with the euro area in general and the hypothesis that these economies will experience larger positive growth spillovers from the euro area in response to the EAPP. Finally, exchange rates depreciated more in economies in which the scope for carry trades was larger, as reflected by larger interest rate differentials with the euro area. This finding is consistent with the hypothesis that the EAPP increased the attractiveness of carry trades by lowering volatility in financial markets - a measure of the price of a carry trade - and that high-yield currencies benefited more from the increased carry trade activity. Moreover, this is consistent with the importance of the confidence channel for the transmission of the EAPP to global equity prices discussed in Section 3.2.2, the latter increased more strongly in economies which investors would typically consider as more risky assets (again as reflected by higher interest rate differentials). The lack of statistically significant coefficient estimates for cross-country heterogeneities in the responses of bond yields to the EAPP announcement is consistent with our finding of rather limited global spillovers to bond markets.

\section{Conclusion}

In this paper we evaluate the global financial market responses to the ECB's announcement of EAPP and compare them to those of previous ECB announcements of unconventional monetary policy measures. We find that the EAPP announcement caused a broad-based depreciation of the euro and increases in domestic and global equity prices. Moreover, only the EAPP announcement had an immediate impact on the euro exchange rate, and it did so mainly through the signalling channel. Euro area equities benefited only from the EAPP and the OMT announcements; confidence effects were more important 
with the OMT announcement, and portfolio re-balancing and signalling channel with the EAPP announcement. Finally, while global equity prices responded to all announcements of ECB unconventional monetary policy measures confidence effects were dominant for the EAPP and the OMT but portfolio re-balancing for the SMP announcement.

Future research should examine the extent to which the impact of the ECB's EAPP announcement has been persistent and transmitted to the macroeconomy in terms of output growth and inflation in the euro area, possibly in a similar vein to Altavilla et al. (2014). Similarly, future research should also evaluate the extent to which the EAPP has generated sustained capital flows to emerging market economies.

\section{References}

Ahmed, S., Zlate, A., 2014. Capital Flows to Emerging Market Economies: A Brave New World? Journal of International Money and Finance 48 (PB), 221-248.

Altavilla, C., Giannone, D., Lenza, M., Jan. 2014. The Financial and Macroeconomic Effects of the OMT Announcements. CSEF Working Papers 352, Centre for Studies in Economics and Finance (CSEF), University of Naples, Italy.

Bauer, M., Neely, C., 2014. International Channels of the Fed's Unconventional Monetary Policy. Journal of International Money and Finance 44 (C), 24-46.

Bowman, D., Londono, J., Sapriza, H., 2014. U.S. Unconventional Monetary Policy and Transmission to Emerging Market Economies. International Finance Discussion Papers 1109, Board of Governors of the Federal Reserve System.

Ehrmann, M., Fratzscher, M., 2005. Equal Size, Equal Role? Interest Rate Interdependence Between the Euro Area and the United States. Economic Journal 115 (506), $928-948$.

Fic, T., 2013. The Spillover Effects of Unconventional Monetary Policies in Major Developed on Developing Countries. DESA Working Papers 131. 
Fratzscher, M., Lo Duca, M., Straub, R., 2013. On the International Spillovers of US Quantitative Easing. ECB Working Paper 1557.

Fratzscher, M., Lo Duca, M., Straub, R., 2014. ECB Unconventional Monetary Policy Actions: Market Impact, International Spillovers and Transmission Channels. Paper presented at the 15th Jacques Polak Annual Research Conference.

Kawai, M., 2015. International Spillovers of Monetary Policy: US Federal Reserve's Quantitative Easing and Bank of Japan's Quantitative and Qualitative Easing. ADBI Working Papers 512.

Martin, P., Rey, H., 2004. Financial Super-Markets: Size Matters for Asset Trade. Journal of International Economics 64 (2), 335-361.

Moore, J., Nam, S., Suh, M., Tepper, A., 2013. Estimating the Impacts of U.S. LSAPs on Emerging Market Economies' Local Currency Bond Markets. Staff Reports 595, Federal Reserve Bank of New York.

Neely, C., 2010. The Large Scale Asset Purchases Had Large International Effects. Working Papers 2010-018, Federal Reserve Bank of St. Louis.

Portes, R., Rey, H., 2005. The Determinants of Cross-border Equity Flows. Journal of International Economics 65 (2), 269-296.

Rogers, J., Scotti, C., Wright, J., 2014. Evaluating Asset-Market Effects of Unconventional Monetary Policy: A Cross-Country Comparison. International Finance Discussion Papers 1101, Board of Governors of the Federal Reserve System. 


\section{A Tables}

Table 1: List of Countries Included in the Sample and Summary Statistics for the Dependent Variables

\begin{tabular}{|c|c|c|c|c|c|c|c|}
\hline \multirow[t]{2}{*}{ Group } & \multirow[t]{2}{*}{ Country } & \multicolumn{2}{|c|}{ Euro exchange rate } & \multicolumn{2}{|c|}{ Bond yields } & \multicolumn{2}{|c|}{ Equity returns } \\
\hline & & Mean & Std Dev & Mean & Std Dev & Mean & Std Dev \\
\hline US & USA & -0.005 & 0.633 & -0.001 & 0.065 & 0.026 & 1.375 \\
\hline Japan & $\mathrm{JPN}$ & -0.004 & 0.869 & -0.001 & 0.023 & 0.014 & 1.619 \\
\hline NonEA-EU & $\mathrm{CZE}$ & 0.002 & 0.475 & -0.002 & 0.052 & -0.012 & 1.573 \\
\hline NonEA-EU & DNK & 0.000 & 0.016 & -0.002 & 0.051 & 0.028 & 1.242 \\
\hline NonEA-EU & GBR & 0.007 & 0.535 & -0.002 & 0.054 & 0.012 & 1.292 \\
\hline NonEA-EU & HRV & 0.002 & 0.181 & - & - & -0.020 & 1.322 \\
\hline NonEA-EU & HUN & 0.012 & 0.709 & -0.002 & 0.131 & -0.005 & 1.686 \\
\hline NonEA-EU & POL & 0.006 & 0.670 & -0.002 & 0.053 & 0.005 & 1.061 \\
\hline NonEA-EU & $\mathrm{ROU}$ & 0.013 & 0.408 & -0.005 & 0.038 & 0.008 & 1.690 \\
\hline NonEA-EU & SWE & 0.003 & 0.510 & -0.002 & 0.046 & 0.025 & 1.431 \\
\hline Other Advanced & AUS & -0.004 & 0.775 & -0.002 & 0.066 & 0.006 & 1.180 \\
\hline Other Advanced & $\mathrm{CAN}$ & -0.001 & 0.620 & -0.001 & 0.046 & 0.016 & 1.305 \\
\hline Other Advanced & $\mathrm{CHE}$ & -0.018 & 0.653 & -0.001 & 0.035 & 0.005 & 1.217 \\
\hline Other Advanced & ISL & 0.029 & 1.095 & -0.001 & 0.042 & -0.054 & 1.888 \\
\hline Other Advanced & NOR & 0.004 & 0.533 & -0.002 & 0.048 & 0.034 & 1.778 \\
\hline Other Advanced & NZL & -0.006 & 0.762 & -0.001 & 0.046 & 0.019 & 0.726 \\
\hline CEMEA & DZA & 0.010 & 0.822 & - & - & - & - \\
\hline CEMEA & ISR & -0.001 & 0.665 & -0.004 & 0.037 & 0.027 & 1.167 \\
\hline CEMEA & MAR & -0.001 & 0.247 & - & - & 0.006 & 0.778 \\
\hline CEMEA & RUS & 0.043 & 0.922 & 0.000 & 0.106 & 0.023 & 2.234 \\
\hline CEMEA & TUR & 0.021 & 0.831 & -0.003 & 0.106 & 0.054 & 1.738 \\
\hline CEMEA & $\mathrm{ZAF}$ & 0.021 & 1.004 & 0.000 & 0.067 & 0.043 & 1.399 \\
\hline LatAm & $\mathrm{ARG}$ & 0.044 & 0.695 & - & - & 0.088 & 2.015 \\
\hline LatAm & BRA & 0.011 & 1.013 & 0.000 & 0.104 & 0.020 & 1.821 \\
\hline LatAm & MEX & 0.011 & 0.801 & -0.002 & 0.059 & 0.029 & 1.322 \\
\hline Asia & $\mathrm{CHN}$ & -0.016 & 0.635 & 0.000 & 0.034 & 0.040 & 1.832 \\
\hline Asia & HKG & -0.005 & 0.631 & -0.001 & 0.052 & 0.024 & 1.688 \\
\hline Asia & IDN & 0.013 & 0.880 & -0.001 & 0.169 & 0.061 & 1.438 \\
\hline Asia & IND & 0.011 & 0.711 & 0.000 & 0.066 & 0.048 & 1.570 \\
\hline Asia & KOR & 0.005 & 0.922 & -0.001 & 0.047 & 0.024 & 1.380 \\
\hline Asia & MYS & -0.004 & 0.650 & 0.000 & 0.034 & 0.029 & 0.810 \\
\hline Asia & PHL & -0.010 & 0.663 & -0.001 & 0.049 & 0.053 & 1.328 \\
\hline Asia & SGP & -0.012 & 0.483 & -0.001 & 0.048 & 0.015 & 1.231 \\
\hline Asia & THA & -0.009 & 0.731 & -0.001 & 0.055 & 0.049 & 1.317 \\
\hline Asia & TWN & -0.007 & 0.611 & 0.000 & 0.023 & 0.017 & 1.269 \\
\hline
\end{tabular}

Source: Daily data on bilateral euro exchange rates, 10-year government bond yields and stock market indices are taken from Bloomberg. Exchange rates are based on New York fixing times. Equity and bond prices are based on local closing times. 
Table 2: Global Financial Market Impact of ECB EAPP Announcement on 22 January 2015 for Major Countries and Country Groups

\begin{tabular}{lccc}
\hline & $\begin{array}{c}\text { Euro } \\
\text { exchange rate }\end{array}$ & $\begin{array}{c}\text { Equity } \\
\text { returns }\end{array}$ & $\begin{array}{c}\text { Bond } \\
\text { yields }\end{array}$ \\
\hline E-change & $\%$-change & $\begin{array}{c}\text { Change in } \\
\text { percent. points }\end{array}$ \\
Euro area & $-1.78^{* * *}$ & $1.65^{* * *}$ & $-0.07^{* * *}$ \\
\hline US & $-2.12^{* * *}$ & $1.53^{* * *}$ & 0.00 \\
Japan & $-1.66^{* * *}$ & -0.01 & $-0.08^{* * *}$ \\
Non-EA EU & $-1.03^{* * *}$ & $0.94^{* * *}$ & -0.01 \\
Other Advanced & $-1.04^{* * *}$ & $0.83^{*}$ & -0.01 \\
\hline Advanced (ex. EA) & $-1.35^{* * *}$ & $1.11^{* * *}$ & $-0.02+$ \\
\hline CEMEA & $-3.11^{* * *}$ & $1.86^{*}$ & -0.02 \\
LatAm & $-2.95^{* * *}$ & $0.87+$ & 0.03 \\
Asia & $-2.14^{* * *}$ & $2.52^{* *}$ & $-0.02^{* *}$ \\
\hline Emerging market economies & $-2.42^{* * *}$ & $2.15^{* *}$ & $-0.02+$ \\
\hline
\end{tabular}

Source: Authors' calculations.

Notes: Bilateral euro exchange rate movements against trading partners' currencies. For the euro area the number refers to the nominal effective exchange rate. A negative sign corresponds to euro depreciation. Significance levels refer to the significance of the $\beta_{1}$-coefficient in Equation (1): $+p<0.20,{ }^{*} p<0.10$, ${ }^{* *} p<0.05,{ }^{* * *} p<0.01$. Standard errors are robust to heteroskedasticity.

Table 3: Transmission channel of Global Financial Market Impact of ECB EAPP Announcement on 22 January 2015

\begin{tabular}{|c|c|c|c|c|c|}
\hline & \multicolumn{2}{|c|}{$\begin{array}{l}\text { Portfolio rebalancing } \\
\text { channel }\end{array}$} & \multirow{3}{*}{$\begin{array}{c}\begin{array}{c}\text { Signalling } \\
\text { channel }\end{array} \\
\text { Inflation } \\
\text { expectations } \\
\text { Change in } \\
\text { percent. points }\end{array}$} & \multicolumn{2}{|c|}{ Confidence channel } \\
\hline & Bond flows & Equity flows & & VIX & $\begin{array}{c}\text { Intra-EA } \\
\text { spread }\end{array}$ \\
\hline & $\%$-change & $\%$-change & & Change & $\begin{array}{l}\text { Change in } \\
\text { percent. points }\end{array}$ \\
\hline Euro area & $0.25^{* * *}$ & $0.44^{* * *}$ & $0.08^{* * *}$ & & $-0.07^{* * *}$ \\
\hline US & $0.48^{* * *}$ & $-0.26^{* * *}$ & & & \\
\hline Japan & $0.15^{* * *}$ & $-0.24^{* * *}$ & & & \\
\hline Advanced (ex. EA) & $0.40^{* * *}$ & $-0.17^{* * *}$ & & & \\
\hline CEMEA & $0.19^{* *}$ & -0.05 & & & \\
\hline LatAm & 0.03 & $-0.17^{* * *}$ & & & \\
\hline Asia & 0.05 & $-0.15^{* * *}$ & & & \\
\hline EMEs & 0.06 & $-0.16^{* * *}$ & & & \\
\hline Global & & & & $-2.46^{* * *}$ & \\
\hline
\end{tabular}

Source: Authors' calculations.

Significance levels refer to the significance of the $\beta_{1}$-coefficient in Equation (1): $+p<0.20,{ }^{*} p<0.10$, ${ }^{* *} p<0.05$, *** $p<0.01$. Standard errors are robust to heteroskedasticity. 
Table 4: Global Financial Market Impact of OMT and SMP Announcements for Major Countries and Country Groups

\begin{tabular}{|c|c|c|c|c|c|c|}
\hline & \multicolumn{2}{|c|}{ Euro exchange rate } & \multicolumn{2}{|c|}{ Equity returns } & \multicolumn{2}{|c|}{ Bond yields } \\
\hline & OMT & SMP & OMT & SMP & OMT & SMP \\
\hline & \multicolumn{2}{|c|}{ \%-change } & \multicolumn{2}{|c|}{ \%-change } & \multicolumn{2}{|c|}{ Change in percent. points } \\
\hline Euro area & $0.25+$ & 0.01 & $3.68 * * *$ & 3.24 & $0.06^{* * *}$ & 0.04 \\
\hline US & $0.79^{* *}$ & 0.35 & $1.72^{* * *}$ & -1.22 & $0.05^{* * *}$ & -0.07 \\
\hline Japan & $1.09^{* * *}$ & 0.58 & $-0.40+$ & $-1.91^{* *}$ & 0.01 & $0.02^{*}$ \\
\hline Non-EA EU & -0.33 & $-0.45+$ & $1.29 * * *$ & $0.64^{*}$ & $0.03^{*}$ & 0.00 \\
\hline Other Advanced & 0.01 & $-0.44^{* *}$ & $1.07 * * *$ & -0.38 & $0.05^{* * *}$ & 0.04 \\
\hline Advanced (ex. EA) & 0.13 & -0.15 & $1.24^{* * *}$ & $-0.92^{* * *}$ & $0.04^{* * *}$ & -0.03 \\
\hline CEMEA & -0.10 & $0.45+$ & $1.43^{* * *}$ & $-1.89^{*}$ & $-0.05^{* * *}$ & -0.04 \\
\hline LatAm & 0.17 & -0.23 & $1.88^{*}$ & $-1.96^{* * *}$ & $0.04^{*}$ & -0.10 \\
\hline Asia & $0.62^{* * *}$ & $0.20^{*}$ & -0.03 & $-0.55+$ & $0.01+$ & $-0.03^{* * *}$ \\
\hline EMEs & $0.42^{* *}$ & $0.22^{* *}$ & $0.50+$ & $-0.97^{* *}$ & 0.01 & $-0.04^{* *}$ \\
\hline
\end{tabular}

Source: Authors' calculations.

Notes: Bilateral euro exchange rate movements against trading partners' currencies. For the euro area the number refers to the nominal effective exchange rate. A negative sign corresponds to euro depreciation. Significance levels refer to the significance of the $\beta_{1}$-coefficient in Equation (1): $+p<0.20,{ }^{*} p<0.10$, ${ }^{* *} p<0.05,{ }^{* * *} p<0.01$. Standard errors are robust to heteroskedasticity. 


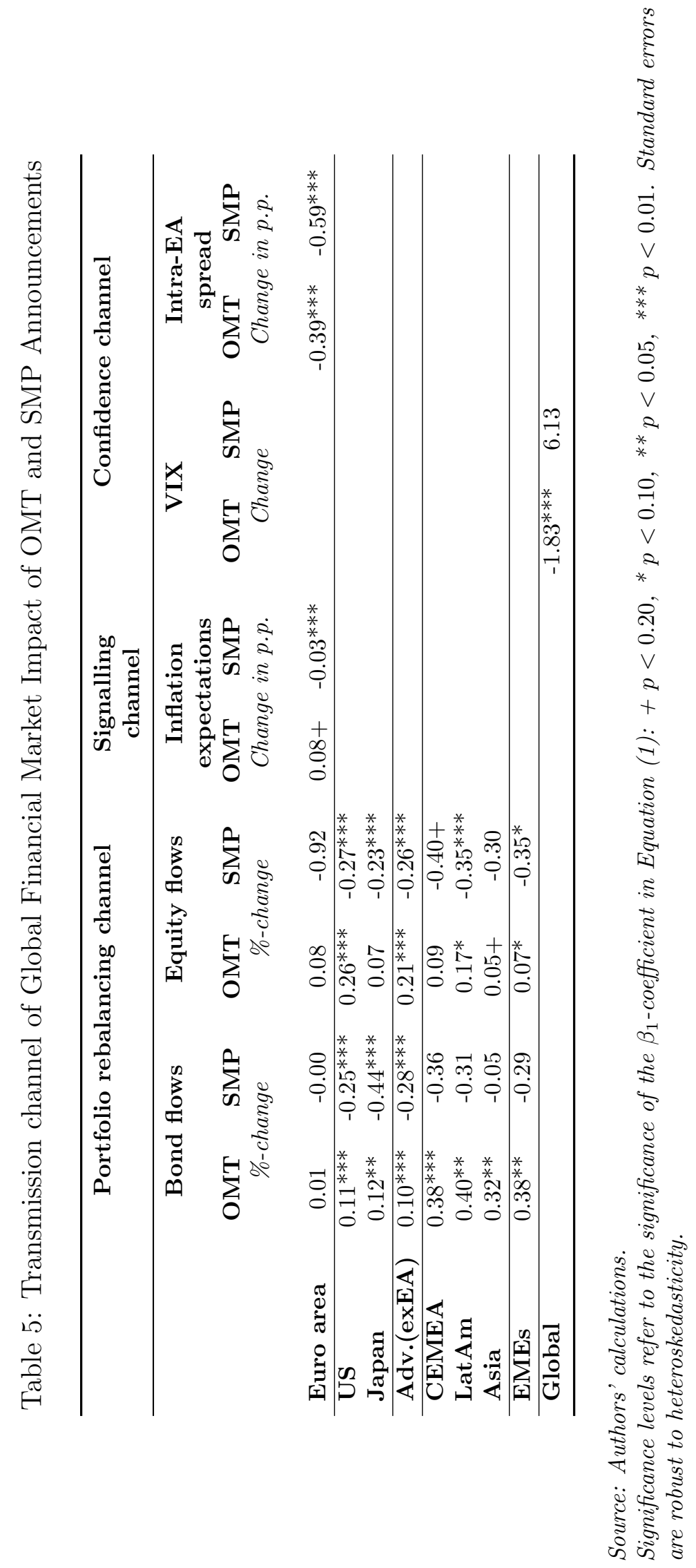


Table 6: Robustness check: Variation in fixing times and set of EAPP announcements

\begin{tabular}{|c|c|c|c|c|c|c|}
\hline & \multicolumn{2}{|c|}{ Euro exchange rate } & \multicolumn{2}{|c|}{ Equity returns } & \multicolumn{2}{|c|}{ Bond yields } \\
\hline & $\begin{array}{l}\text { London } \\
\text { fixing }(\mathrm{t})\end{array}$ & $\begin{array}{c}\text { Announcement } \\
(4 \operatorname{Sep} 2014+ \\
\text { 22Jan2015) }\end{array}$ & $\begin{array}{c}\text { Opening } \\
\text { price }(\mathrm{t}+1)\end{array}$ & $\begin{array}{l}\text { Announce. } \\
(4 \mathrm{Sep} 2014+ \\
\text { 22Jan2015) }\end{array}$ & $\begin{array}{c}\text { Closing } \\
\text { price }(t+1)\end{array}$ & $\begin{array}{l}\text { Announce. } \\
(4 \mathrm{Sep} 2014+ \\
\text { 22Jan2015) }\end{array}$ \\
\hline & \multicolumn{2}{|c|}{$\%$-change } & \multicolumn{2}{|c|}{$\%$-change } & \multicolumn{2}{|c|}{ Change in p.p. } \\
\hline Euro area & $-1.55^{* * *}$ & $-1.29^{* * *}$ & $0.52^{* * *}$ & $0.57^{* * *}$ & $-0.08 * * *$ & -0.03 \\
\hline US & $-1.67 * * *$ & $-1.55^{* * *}$ & $0.67^{* * *}$ & 0.31 & $-0.06^{* * *}$ & 0.02 \\
\hline Japan & $-1.53^{* * *}$ & $-1.33^{* * *}$ & -0.01 & $-0.31+$ & $-0.08 * * *$ & -0.04 \\
\hline Non-EA EU & $-0.99 * * *$ & $-0.76 * * *$ & $1.18^{* * *}$ & $0.90 * * *$ & $-0.07 * *$ & -0.00 \\
\hline Other Adv. & $-1.08 * * *$ & $-0.81^{* *}$ & $1.13+$ & $0.66+$ & 0.01 & 0.00 \\
\hline Adv. (ex. EA) & $-1.22^{* * *}$ & $-1.01^{* * *}$ & $0.72^{* * *}$ & $0.36^{* *}$ & $-0.05^{* * *}$ & 0.01 \\
\hline CEMEA & $-2.65 * * *$ & $-1.83^{* * *}$ & $2.01^{* *}$ & $2.10^{*}$ & -0.02 & $-0.03^{* * *}$ \\
\hline LatAm & $-2.82^{* * *}$ & $-2.00 * * *$ & $2.21^{* *}$ & $1.35^{* * *}$ & -0.14 & 0.04 \\
\hline Asia & $-1.76^{* * *}$ & $-1.62^{* * *}$ & $2.52^{* *}$ & $1.63^{* *}$ & $-0.02^{*}$ & $-0.01+$ \\
\hline EMEs & $-2.03^{* * *}$ & $-1.69 * * *$ & $2.39 * * *$ & $1.65^{* * *}$ & $-0.04^{*}$ & -0.01 \\
\hline
\end{tabular}

Source: Authors' calculations.

Notes: Bilateral euro exchange rate movements against trading partners' currencies. For the euro area the number refers to the nominal effective exchange rate. A negative sign corresponds to euro depreciation. Significance levels refer to the significance of the $\beta_{1}$-coefficient in Equation (1): $+p<0.20,{ }^{*} p<0.10$, ${ }^{* *} p<0.05,{ }^{* * *} p<0.01$. Standard errors are robust to heteroskedasticity. 
Table 7: Determinants of Cross-country Heterogeneities in Global Financial Market Impact of the EAPP Announcement

\begin{tabular}{|c|c|c|c|}
\hline & $\begin{array}{l}\text { (1) } \\
\text { FX }\end{array}$ & $\begin{array}{c}(2) \\
\text { Equities }\end{array}$ & $\begin{array}{c}(3) \\
\text { Bonds }\end{array}$ \\
\hline Distance to EA & $\begin{array}{l}0.27^{* *} \\
(0.04)\end{array}$ & $\begin{array}{c}0.20 \\
(0.43)\end{array}$ & $\begin{array}{c}0.02 \\
(0.45)\end{array}$ \\
\hline GDP (log) & $\begin{array}{c}-0.12^{* *} \\
(0.05)\end{array}$ & $\begin{array}{c}0.23^{* *} \\
(0.02)\end{array}$ & $\begin{array}{l}-0.00 \\
(0.71)\end{array}$ \\
\hline GFAL rel. to GDP & $\begin{array}{c}-0.49^{* * *} \\
(0.01)\end{array}$ & $\begin{array}{l}0.50^{*} \\
(0.10)\end{array}$ & $\begin{array}{r}-0.03^{+} \\
(0.13)\end{array}$ \\
\hline Bil. fin. integration with EA & $\begin{array}{c}3.46^{* * *} \\
(0.00)\end{array}$ & $\begin{array}{c}0.20 \\
(0.88)\end{array}$ & $\begin{array}{c}0.12 \\
(0.21)\end{array}$ \\
\hline Bil. trade integration with EA & $\begin{array}{l}1.15^{+} \\
(0.16)\end{array}$ & $\begin{array}{l}4.25^{* *} \\
(0.02)\end{array}$ & $\begin{array}{l}-0.04 \\
(0.84)\end{array}$ \\
\hline Interest rate differential i - EA (2-year) & $\begin{array}{c}-0.14^{* * *} \\
(0.00)\end{array}$ & $\begin{array}{l}0.11^{*} \\
(0.05)\end{array}$ & $\begin{array}{l}-0.01 \\
(0.39)\end{array}$ \\
\hline ER flexibility & $\begin{array}{c}-0.06^{* *} \\
(0.02)\end{array}$ & & \\
\hline Observations & 31 & 31 & 31 \\
\hline Adjusted $R^{2}$ & 0.76 & 0.19 & -0.05 \\
\hline
\end{tabular}




\section{B Figures}

Figure 1: Comparison of Global Financial Market Impact Across ECB Announcements of Major Unconventional Measures
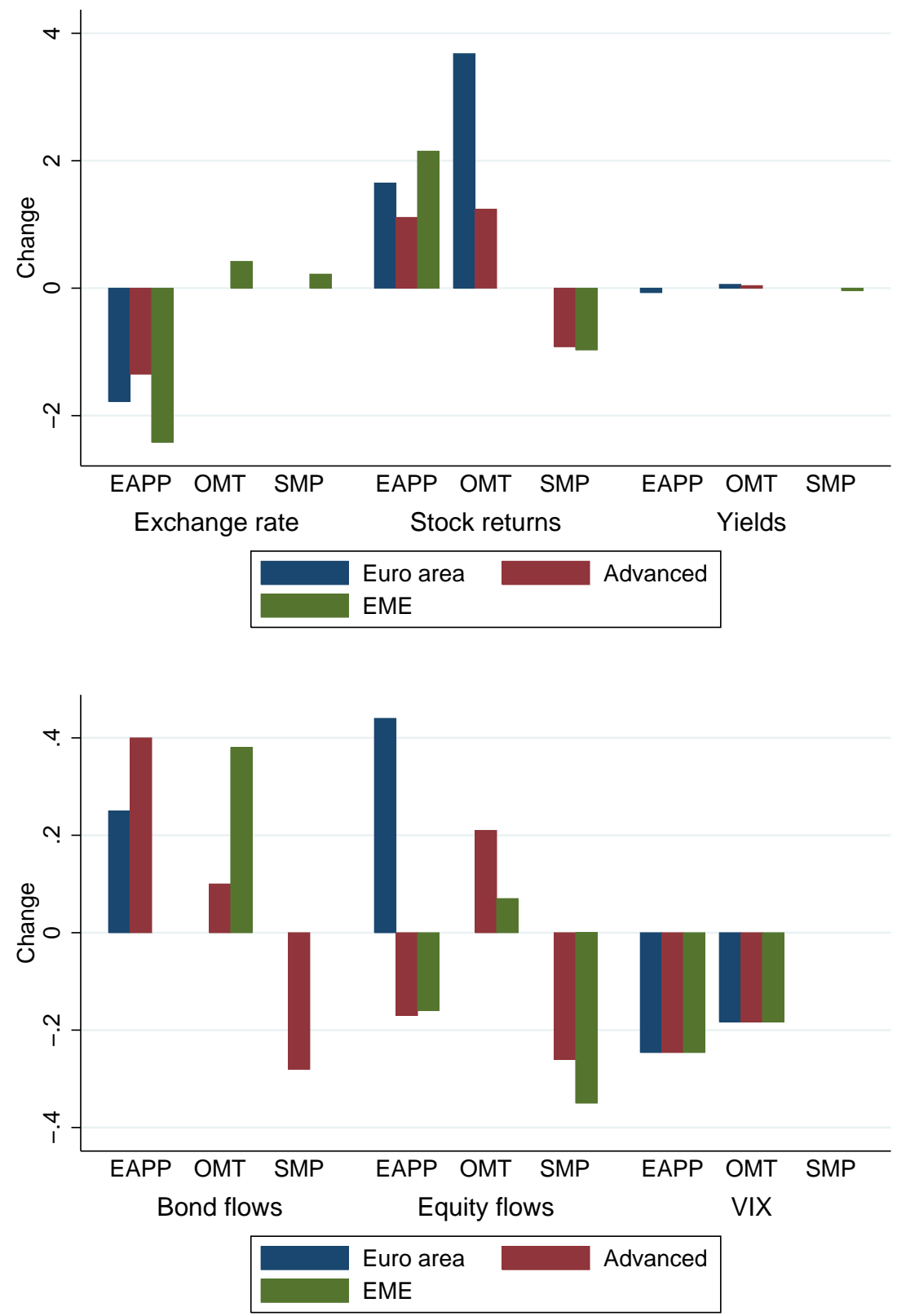

Notes: The upper panel displays the effects of the ECB's EAPP, OMT and SMP announcements on asset prices, separately for the euro area, advanced economies (excl. the euro area) and emerging market economies. The lower panel displays the effects on the transmission channels. The results for the VIX are identical across groups as the VIX is a global variable. Results for the VIX are divided by 10 in order to make the right-hand side panel easier to read. We only report results that are statistically significant at least at the $10 \%$ significance level. 